\title{
A bamboo braced frame system for tropical climates
}

\section{Un sistema de construcción para climas tropicales basado en pórticos arriostrados de bambú}

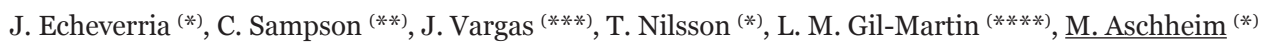

\begin{abstract}
A low-cost housing system was developed for use in tropical countries, specifically Haiti, with the aims of minimizing environmental impact (including carbon emissions), maximizing use of local and preferably recycled materials, and using local labor. The housing system integrates low-strength concrete blocks (made using recycled concrete aggregate), an innovative seismically-resistant bamboo frame, earthen plasters, bamboo trusses, and metal deck roofs. The bamboo frame relies on flexural yielding of a short rebar dowel to provide ductile performance at a controlled strength level. The plinth walls below the frame and short rebar dowel protects the bamboo from moisture. The top of a plastic soda bottle is used to protect the rebar from moisture and to seal the base of the bamboo culm, allowing mortar to be introduced into the culm above. This paper focuses on the experimental and analytical results of the flexural yielding of the rebar dowel to establish the structural design of this critical component of the system for resisting wind and seismic loads.
\end{abstract}

Keywords: Ecological building; ductile bamboo frame; rebar dowel.

\section{RESUMEN}

En este artículo se presenta un sistema de construcción de viviendas de bajo coste para países tropicales en los cuales existe riesgo sísmico. Los objetivos de este trabajo son generar bajo impacto medioambiental (incluyendo las emisiones de carbono), empleo de materiales locales, preferiblemente reciclados, y mano de obra local. Para esta construcción se han empleado bloques de hormigón de baja resistencia (con agregado reciclado) junto con un innovador sistema de pórticos de bambú, botellas de plástico, vigas de bambú y cubiertas de chapa. El comportamiento dúctil de la estructura se garantiza introduciendo una barra de acero en la base del pórtico de bambú. Para proteger el bambú de la humedad, el pórtico se monta sobre un zócalo. Los resultados experimentales y analíticos obtenidos se utilizan para el diseño estructural del sistema frente a cargas de viento y sísmicas.

Palabras clave: Construcción ecológica; pórtico dúctil de bamboo; pasador corrugado.

(*) Santa Clara University. Santa Clara, CA (USA).

${ }^{(* *)}$ Kiewit Infrastructure West Company. San Bruno, CA (USA).

(***) Devcon Construction. Milpitas, CA (USA).

(****) University of Granada. Granada (Spain).

Persona de contacto/Corresponding author: maschheim@scu.edu (M. Aschheim)

Cómo citar este artículo/Citation: Echeverria, J., Sampson, C., Vargas, J., Nilsson, T., Gil-Martin, L. M., Aschheim, M. (2014). A Bamboo Braced Frame System for Tropical Climates. Informes de la Construcción, 66(EXTRA-1): mo19, doi: http://dx.doi.org/10.3989/ ic.13.122.

Licencia / License: Salvo indicación contraria, todos los contenidos de la edición electrónica de Informes de la Construcción se distribuyen bajo una licencia de uso y distribución Creative Commons Reconocimiento no Comercial 3.o. España (cc-by-nc). 


\section{INTRODUCTION}

On January 12, 2010, a 7.0 magnitude earthquake caused extensive and severe damage to Haiti leaving 1.5 million people displaced. Over 105,000 homes were destroyed and more than 208,00o homes were damaged (1). Several months after the earthquake, the government of Haiti solicited designs for low-cost homes to be demonstrated the Building Back Better Communities (BBBC) exposition. The Ecological Building Network (EBNet) displayed an economical, culturally appropriate home built primarily of locally available materials. The design, which is the subject of this paper, provides two covered porches within the $15-\mathrm{ft}(4.6-\mathrm{m})$ by $24-\mathrm{ft}(7.3-\mathrm{m})$ footprint, with one of these porches containing an outdoor kitchen. There is room for one bath, while interior walls may be provided for private bedrooms. The home has a 9-ft (2.7$\mathrm{m})$ ceiling height with a 5:12 peaked roof overhanging an additional 1.5 - $\mathrm{ft}(0.46-\mathrm{m})$ on each side.

The EBNet design features low-strength concrete block made using recycled concrete rubble aggregate, salvaged reinforcing steel bars for reinforcement, locally-grown bamboo, and locally-sourced earthen plasters. Galvanized corrugated metal roofing is the only major component imported from abroad. The heavy reliance on local materials promotes environmental sustainability and local economic development while avoiding the relatively high cost of imported materials.

The use of concrete rubble and salvaged reinforcing bars addresses the problem of disposing of large quantities of debris resulting from the collapse of reinforced concrete buildings during the earthquake or their subsequent demolition. Most of the estimated 20-million cubic yards of debris is concrete rubble (2). Since aggregate can account for 70 to $80 \%$ of the constituents (by volume) of concrete, the use of crushed concrete rubble as aggregate provides an alternative to landfill of the debris and preserves natural resources. Observations by EBNet (personal communication) and DesRoches, et al. (2) indicate concrete strengths, while low compared with U.S. practice, are more than adequate for our intended application. DesRoches et al. (2) report average compressive strengths of random samples of Haitian concrete to be 1300 psi. When the Haitian concrete samples were crushed and used as fine and coarse aggregate in new batches of concrete, compressive strengths between 3100 psi and 3350 psi could be achieved, using a water/cement ratio of 0.5 . In comparison, strengths of above 5000 psi were achieved when Georgia granite was substituted for the crushed concrete rubble.

Deforestation is widespread in Haiti, and in addition to soil erosion and impacts on agricultural production, makes construction lumber costly and of limited availability (3) (4). Reforestation with species suitable for timber would require decades of growth before harvest, if it was not pre-emptively used for fuel (5) (6) (7). Bamboo is a preferable alternative for reforestation because it can be harvested relatively quickly (8). Guadua Angustifolia, native to Colombia and Ecuador, is already being grown in Haiti. This species can provide quality building material within six years of initial planting; new shoots that emerge after the initial harvest can be harvested every four years (9) (10). This species has excellent structural properties and has the potential to become a valuable cash crop within Haiti.

\section{STRUCTURAL SYSTEM CONCEPT}

\subsection{Proposed structure configuration and dimensions}

The basic structural system is illustrated in Figure 1 (section) and Figure 2 (elevation). The house uses bamboo roof trusses at $4-\mathrm{ft}(1.22-\mathrm{m})$ centers that are supported by bamboo braced frames. The frames are supported by 3 - $\mathrm{ft}$ (0.9-m) high masonry plinth walls, which are composed of concrete masonry units (CMUs) made from recycled concrete rubble. The masonry plinths raise the bamboo frames above ground to protect them from ground moisture and rain splash.

The braced bamboo frames are assembled on the ground, then raised into place and set onto the previously constructed masonry plinth walls. Lath and plaster (or wattle and daub) is applied to the bamboo framing. To protect the bamboo from moisture in the plaster, the lath is held off the bamboo frames using recycled bottle caps as spacers. Bamboo roof trusses are built onsite, and set into place bearing on the top member of the braced frames. Purlins may consist of nominal 1-in. by 4-in. (25.4-mm $\times 50.8-\mathrm{mm}$ ) boards spaced approximately 8-in. (101.6 $\mathrm{mm}$ ) apart are used to support a corrugated sheet metal roof. Sheet metal roofs are often used in Haiti. Since the roof functions as a diaphragm for resisting lateral loads, diagonal bracing may be needed to provide sufficient capacity for larger diaphragm spans.

The 3-ft. (0.9 m) high CMU plinth wall is supported on a continuous strip footing. The CMU blocks are fabricated on site by hand-tamping a concrete mix into metal molds. A lowstrength concrete made using crushed concrete rubble as ag-

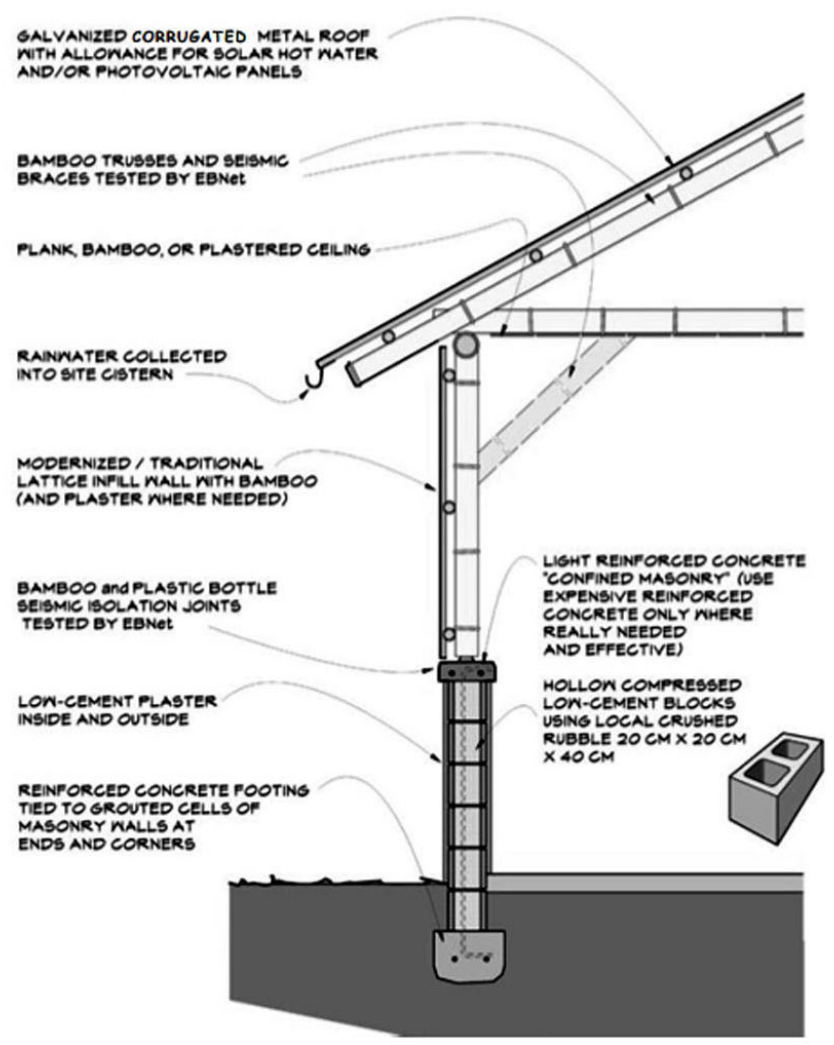

Figure 1. Section (courtesy B. King). 


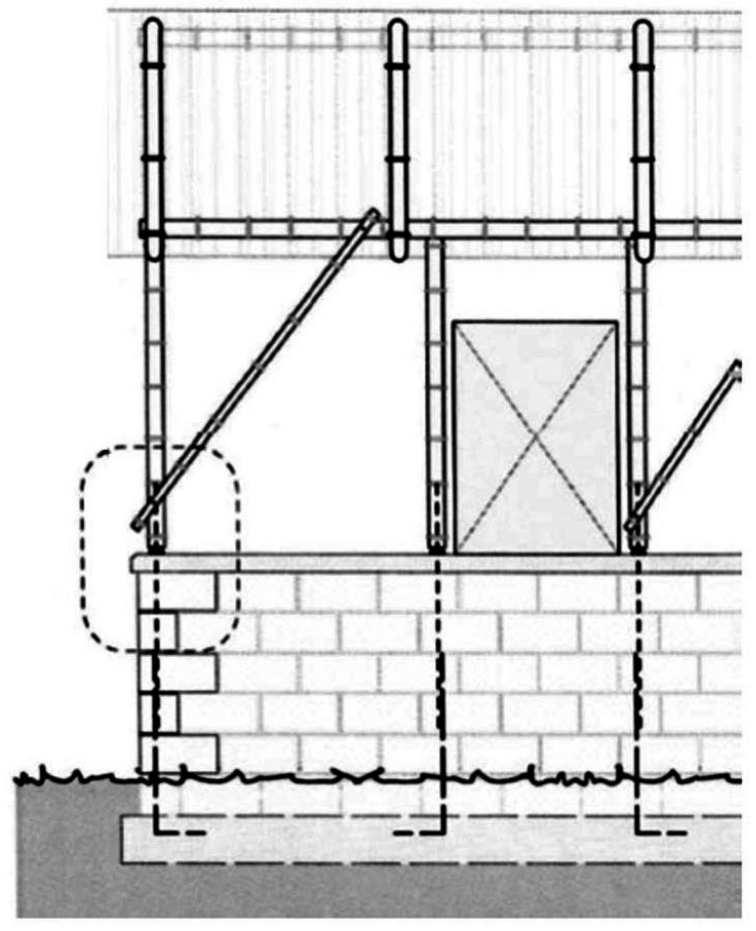

Figure 2. Elevation (courtesy B. King).

gregate is used (approximately $300 \mathrm{psi}(2 \mathrm{MPa})$ compressive strength at 3 days), to minimize cement content. The CMU plinth wall is not load bearing, but serves as a form for castin-void reinforced concrete. Within select CMU cells where the bamboo frame columns attach, a No. 3 deformed rebar runs continuously from the foundation within mortar-filled CMU cells. The bamboo frame is held approximately 2- to 3 -inches (50 to $75-\mathrm{mm}$ ) above the CMU plinth walls, exposing the No. 3 rebar and creating a ductile connection, which is the focus of this paper. After the braced frame has been lowered onto the rebar, the bamboo culm containing rebar is filled with mortar by injection through a small hole in the culm wall by means of a grout bag.

A capacity design principle was utilized to provide lateral resistance to earthquake loading. The intended mechanism consists of plastic hinging within the short length of exposed rebar. Hinging of the rebar limits the forces that can be developed at the connections within the bamboo frame, allowing the frame to be designed to remain elastic. To protect the 2-in. (50-mm) exposed rebar from corrosion, the top of a plastic bottle is slipped over the exposed rebar and embedded in the CMU plinth mortar during construction of the masonry wall. The bamboo culm is placed on top of the plastic bottle top, enclosing the protruding rebar, while preventing subsequently applied mortar from leaking out of the base of the culm.
Table 1. 28-day Cube Strengths using w/c = 1.4

\begin{tabular}{|l|c|c|}
\hline Cement Brand & $\begin{array}{c}\text { Average Cube } \\
\text { Compressive } \\
\text { Strength, psi } \\
\text { (MPa) }\end{array}$ & $\begin{array}{c}\text { Compressive } \\
\text { Strength Relative } \\
\text { to US Cement }\end{array}$ \\
\hline Kolos & $415(2.86)$ & 0.42 \\
\hline National & $533(3.67)$ & 0.54 \\
\hline Verraux & $570(3.93)$ & 0.58 \\
\hline $\begin{array}{l}\text { Quikrete } \\
\text { (US Source) }\end{array}$ & $984(6.78)$ & 1.00 \\
\hline
\end{tabular}

\subsection{Low-strength concrete mix design}

Low-strength concrete mix designs were developed for use in making the CMUs. Experiments were conducted using Type I Portland cements sourced in Haiti and the United States, together with aggregates sourced in the U.S. As illustrated in Table 1 , compressive strengths of 2 -in $\times 2$-in $(50.8 \mathrm{~mm} \times$ $50.8 \mathrm{~mm}$ ) cubes obtained using Haitian cements were 42 to 58 percent of those obtained with a U.S. cement for otherwise identical mix designs. The 28-day strengths were obtained for a water/cement ratio of 1.4 and approximate quantities by weight of cement (1), water (1.4), coarse aggregate (3), and sand (9). Reasons for the noticeable disparity in comparison with U.S. cements are being investigated. Given the apparent difference in cement quality and the reduced strengths obtained using recycled Haitian concrete as aggregate, mix designs should be finalized using locally sourced constituents.

\subsection{Mechanical properties of Guadua Angustifolia}

The structural system utilizes 3 to 4 in. (75 to $100 \mathrm{~mm}$ ) diameter culms of Guadua Angustifolia. Because the forces in the bamboo frames are limited by the strength of the rebar dowel, the culms have ample strength. Reported strengths of Guadua Angustifolia vary with age at harvest and the height at which a sample was removed from the culm. For reference, ranges for mechanical properties of Guadua Angustifolia reported by others are summarized in Table 2 (11) (12) (13) (14).

\subsection{Bamboo to CMU connection - dowel configuration}

Figure 3 details the rebar dowel used at the base of each culm at the connection to the masonry plinth. Using the principles of capacity design, the rebar dowel is the ductile weak link in the system, conferring ductility to the system while limiting the forces that develop within the bamboo braced frame and its connections. Dowels having exposed lengths of 2- to 3 -in. (50- to $75-\mathrm{mm}$ ) are considered to be the most practical to build with. Subsequent sections address the number of No. 3 (9.5-mm diameter) dowels of varied lengths that are required to resist seismic and wind loads for the prototype building.

Table 2. Reported Mechanical Properties for Guadua Angustifolia Bamboo.

\begin{tabular}{|l|c|c|c|c|}
\hline \multirow{2}{*}{ Property } & \multirow{2}{*}{$\begin{array}{c}\text { Trujillo (2009) } \\
\text { (based on 5th percentile } \\
\text { values) ksi (MPa) }\end{array}$} & $\begin{array}{c}\text { Minimum, ksi } \\
\text { (MPa) }\end{array}$ & $\begin{array}{c}\text { Average, ksi } \\
\text { (MPa) }\end{array}$ & $\begin{array}{c}\text { Maximum, ksi } \\
\text { (MPa) }\end{array}$ \\
\cline { 3 - 5 } & $4.06-5.51(28.0-38.0)$ & $3.00(20.7)$ & $6.37(43.9)$ & $12.1(83.4)$ \\
\hline Compression Parallel to Grain, $\mathrm{f}_{\mathrm{c}}$ & $5.08(35.0)$ & $5.11(35.2)$ & $7.76(53.5)$ & $24.7(170.3)$ \\
\hline Tension Parallel to Grain, $\mathrm{f}_{\mathrm{t}}$ & $6.67(46.0)$ & $0.71(4.90)$ & $5.44(37.5)$ & $16.3(112.4)$ \\
\hline Bending, $\mathrm{f}_{\mathrm{b}}$ & $0.33(2.28)$ & $0.62(4.27)$ & $1.001(6.902)$ & $1.64(11.31)$ \\
\hline Shear, $\mathrm{f}_{\mathrm{v}}$ & &
\end{tabular}




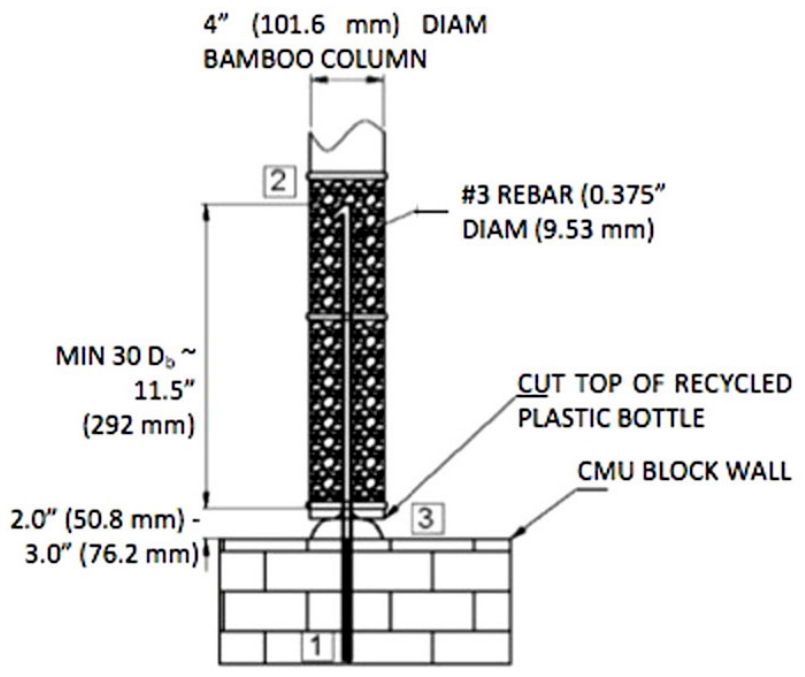

NOTES:

1) EMBEDDED NO. 3 BAR EXTENDS THROUGH CMU WALL INTO FOUNDATION, FOUNDATION NOT PICTURED.

2) 1 INCH $(25 \mathrm{~mm})$-90 DEGREE BEND APLIED TO END OF EMBEDDED BAR PRIOR TO INSERTION AND MORTAR APPLICATION.

3) APPROX. 2 INCH (50.4 mm) OF EXPOSED NO. 3 BAR PROTECTED WITH THE CUT TOP FROM A 2 LITER SODA BOTTLE.

Figure 3. Rebar dowel connection at top of plinth wall.

Construction is achieved using a single No. 3 rebar fabricated with a sharp 90-degree hook with 1-in. (25-mm) extension. Once the frame is installed over the No. 3 rebar, the lowest two intermodal spaces of the culm are filled with mortar to anchor the bar. Laboratory tests indicated rebar embedment into a single internode space within the culm provided adequate strength. However, the diagonal brace frames into the first internode space, and to avoid potential detailing conflicts the brace connection, the vertical No. 3 bar is extended into the second internode space, as shown in Figure 3.

\subsection{Dowel behavior}

Experimental and analytical results (20) led to the following recommendations for future work:

- Although the mortar is able to adequately support the steel rebar when it develops plastic hinges, local crushing of the mortar can occur. A high-strength mortar or fiber reinforced mortar may avoid crushing and hence prevent migration of the rebar plastic hinges. Alternatively, annular inserts made of steel or other materials may be used to reduce bearing stresses between the rebar and mortar and reliably define the dowel's effective length.

- The effective length of dowel should not exceed perhaps $8 \varnothing$, which corresponds to 3 in. $(75 \mathrm{~mm})$ for No. $3(9.5 \mathrm{~mm})$ bars.

- No. 3 (9.5-mm diameter) rebar could be assumed to have yield strength of $43 \mathrm{ksi}(296 \mathrm{MPa})$, and resist a shear of 378 and 252 pounds (1.68 and $1.12 \mathrm{kN}$ ) upon plastic hing- ing at the ends of the 2- and 3 -in. (50- and 75 - $\mathrm{mm}$ ) effective dowel lengths, respectively.

- The effective yield displacements of the dowel are 0.009 and 0.020 in. (0.229 and $0.508 \mathrm{~mm}$ ) for effective lengths of 2 and 3 in. (50 and $75 \mathrm{~mm}$ ), respectively.

- Axial load in the rebar dowel during seismic loading should be limited to $0.40 \mathrm{Py}=0.40(43 \mathrm{ksi})\left(0.20 \mathrm{in}^{2}\right)=3.44 \mathrm{kips}$ $(15 \cdot 3 \mathrm{kN})$.

\section{SEISMIC DESIGN OF STRUCTURE}

\subsection{Braced frame configuration and seismic reactive weight}

The proposed structure (Figure 4) illustrates braced frame configurations and dimensions needed to establish dead loads for use in seismic design. The rebar dowel carries the dead load tributary to each vertical culm, along with any overturning axial forces associated with the lateral load.

Roof dead load was determined to be $2280 \mathrm{lbs}(10.14 \mathrm{kN})$ based on bamboo ( 1.5 plf or $236 \mathrm{~N} / \mathrm{m}$ ), 1x4 wood purlins at 8 in. $(200 \mathrm{~mm})$ centers, galvanized sheet metal roofing ( 0.625 psf or $\left.30 \mathrm{~N} / \mathrm{m}^{2}\right)$, 1 " thick plaster on the gables (85 psf or 4070 $\left.\mathrm{N} / \mathrm{m}^{2}\right)$, and rebar and wire averaging $0.25 \mathrm{psf}\left(12 \mathrm{~N} / \mathrm{m}^{2}\right)$. Wall loads used the same material weights plus $20 \mathrm{lbs}(0.09 \mathrm{kN})$ per mortared bamboo connection for a total structural weight to the frame bases of $\mathrm{W}=9500 \mathrm{lbs}(42.3 \mathrm{kN})$.

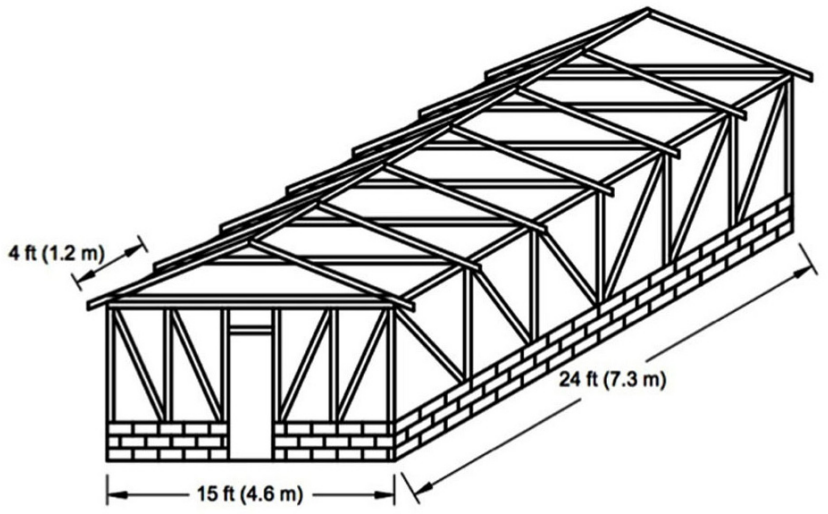

Figure 4. Prototype structural configuration.

\subsection{Inelastic spectra}

The structural system is relatively light in comparison to the concrete and masonry structures typical of Haiti. Consequently, both wind and seismic loading demands were determined with details provided to ensure adequate ductility capacity for seismic loading. Since seismic design is more complex, it is addressed first.

To provide for a nearly universal design for varied site conditions, site specific spectra were established for Site Class D soils on the basis of the USGS Open File Report for Haiti (15). Using standard NEHRP notation, this report provides $S_{S}$ $=1.64 \mathrm{~g}, \mathrm{~S}_{1}=0.61 \mathrm{~g}, \mathrm{~F}_{\mathrm{a}}=1.0$, and $\mathrm{F}_{\mathrm{v}}=1.5$, resulting in design spectral values of $\mathrm{S}_{\mathrm{DS}}=(2 / 3)(1.64 \mathrm{~g})(1.0)=1.09 \mathrm{~g}$ and $\mathrm{S}_{\mathrm{D} 1}=$ $(2 / 3)(0.61 \mathrm{~g})(1.5)=0.61 \mathrm{~g}$.

Inelastic spectra in the form of Yield Point Spectra are plotted in Figure 5. Curves of constant ductility, $\mu$, (estimated 
using the $\mathrm{R}-\mathrm{C}_{1}-\mathrm{T}$ relationship of FEMA 440 (16) are plotted against the axes of yield strength coefficient, $\mathrm{C}_{\mathrm{y}}$, and system yield displacement $\left(\Delta_{\text {system_yield }}\right)$. Thus, using a single-degreeof-freedom (SDOF) system to represent the response of the prototype building, the required strength to limit ductility (and hence, displacement) demands can be established for any estimated yield displacement.

\subsection{System displacements}

The required strength to limit system ductility (and hence peak displacement) is plotted as a function of yield displacement in Figure 5. The roof displacement associated with flexural deformation of the rebar dowel restrained from end rotation is estimated in Tables 3 and 4. In addition, the other structural components members are assumed to undergo elastic deformation. This deformation is assumed to consist of elastic deformation within the bamboo framing members and deformation at the bamboo frame connections. Thus, at effective yield of the system,

$$
\Delta_{\text {system_yield }}=\Delta_{\text {dowel_effective_yield }}+\Delta_{\text {bamboo_deformation }}+\Delta_{\text {slip }}
$$

where $\Delta_{\text {dowel_effective_yeild }}=$ effective yield displacement of the rebar element, $\Delta_{\text {bamboo deformation }}=$ the contribution of deformations within the bamboo framing members to the roof displacement, and $\Delta_{\text {slip }}=$ the contribution of connection slip to roof displacement at the effective yield level load.

Framing member deformations associated with axial loads are very small, while slip at the connection depends heavily on the connection details employed. The sensitivity of the design to connection slip was investigated, assuming connection slip contributes $0.05,0.25$, or 0.5 inches $(1.27,6.35$, or $12.7 \mathrm{~mm}$ ) of lateral displacement at the roof level.

Determination of the ductility demand that can be sustained by the structure depends on the contribution of the capacityprotected members to roof displacement. Since the system displacement results from inelastic demand concentrated within the rebar dowel, the allowable system ductility depends on the displacement that can be tolerated by the rebar dowel. Because the large inherent ductility of the steel com-

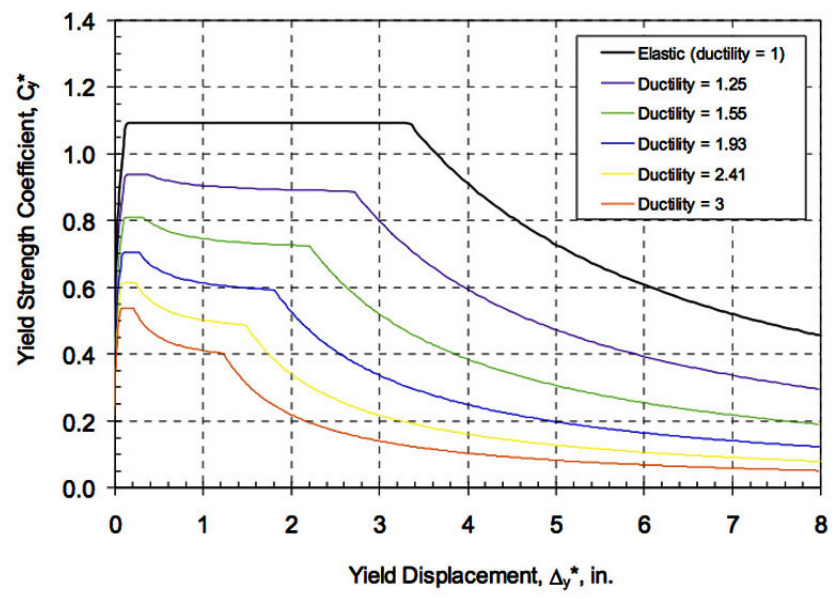

Figure 5. Portion of Yield Point Spectra (Aschheim and Black, 2000) showing yield strength coefficients associated with different ductility demands (19). prising the rebar dowel, the displacement limit for the dowel was derived by imposition of limits associated with P-Delta effects.

Caltrans and AASHTO limits on P-Delta effects were considered in establishing the amount of deformation sustained by the rebar dowel. The proposed frame, as detailed in Figure 4, was analyzed at the effective yield strength corresponding to plastification of the rebar dowel to determine the associated overturning axial compression in the rebar dowel, $\mathrm{P}_{\text {OT }}$. Tributary dead loads were considered to establish the gravity load contribution to the dowel axial force, $\mathrm{P}_{\text {gravity }}$. Thus, the governing axial load to determine the limiting displacement of the dowel $\left(\Delta_{\text {limit_P-Delta }}\right)$ considering P-Delta effects on a local member (rebar dowel) basis is given by $\mathrm{P}_{\text {govern }}=\mathrm{P}_{\text {OT }}+\mathrm{P}_{\text {gravity }}$.

Analytic investigations as described in Section IV, show the rebar dowel, having length not exceeding perhaps $8 \mathrm{~F}$, can withstand large displacements without negative post yield effects for $\frac{P_{\text {govern }}}{P_{\text {yield }}} \leq 0.4$. However, to establish a displacement limit, existing limits applicable to bridge construction were applied. AASHTO limits the ratio $\mathrm{P} \times \mathrm{D} / \mathrm{M}_{\mathrm{p}}$ to not exceed 0.25 , while Caltrans Seismic Design Criteria (18) limits the ratio $\mathrm{P} \times \mathrm{D} / \mathrm{M}_{\mathrm{p}}$.to not exceed 0.20 . These limits are applicable to cantilever columns. To explore the sensitivity of the design to this parameter, the AASHTO limit of 0.25 was used together with a more stringent value of 0.10 . For the case of the rebar dowel, modeled as fixed at one end and guided to prevent rotation at the other, the lateral displacement at the top of the rebar dowel, $\mathrm{D}_{\text {lim-P-Delta }}$, would be limited to

$$
\Delta_{\text {lim-P-Delta }} \leq \frac{2 M_{P}}{P_{\text {govern }}}(0.10 \text { or } 0.25)=\frac{V_{\text {yield }} \cdot L}{P_{\text {govern }}}(0.10 \text { or } 0.25)
$$

since $\mathrm{V}_{\text {yield }}=2 \mathrm{M}_{\mathrm{p}} / \mathrm{L}$.

The resulting displacement limit for the system is given by

$$
\Delta_{\text {system_lim }}=\Delta_{\text {lim-P-Delta }}+\Delta_{\text {bamboo_deformation }}+\Delta_{\text {slip }}
$$

The most restrictive P-Delta limit is obtained for the highest axial force. The culm with the largest dead load is considered together with superimposed overturning compression arising from the braced frame resisting lateral loads. The largest tributary weight on a dowel is represented by the weight tributary to any of the columns along the long perimeter wall, away from the corners. The tributary dead load, W, for this column was calculated to be $515 \mathrm{lbs}$. (2.29 kN). Additional overturning axial forces are also present. Thus, $\mathrm{P}_{\text {govern }}$ is taken equal to $1083 \mathrm{lbs}(4.82 \mathrm{kN})$ and $894 \mathrm{lbs}(3.98 \mathrm{kN})$ for 2 and 3-in. (50- and 75-mm) dowel lengths, respectively.

Thus, the limiting system ductility is given by

$$
\mu=\frac{\Delta_{\text {system-lim }}}{\Delta_{\text {system-yield }}}
$$

The above displacement limits and corresponding system ductility limits for rebar dowels of different clear lengths are quantified in Tables 3 and 4 . 


\subsection{Dowels Required for Seismic Resistance}

Using the inelastic spectra plotted in Figure 5, minimum yield strength coefficients $\left(\mathrm{C}_{\mathrm{y}}\right)$ sufficient to limit system ductility to the values of Tables 3 and 4 were determined. Based on the required shear strength at yield, given by $\mathrm{V}_{\mathrm{v}}=\mathrm{C}_{\mathrm{y}} \mathrm{W}$, the required number of rebar dowel connections (n) of a given clear length were determined. Key results are provided in $\mathrm{Ta}-$ bles 3 and 4, for the AASHTO P-Delta limit of 0.25 and for the more restrictive value of 0.10 .
A greater number of yielding dowel segments are needed when P-Delta requirements are satisfied using the more stringent ratio of o.10. Since a long, slender culm is unlikely to cause yielding of a rebar dowel segment, the number of yielding dowel segments refers to those that are mobilized by an adjacent diagonal brace or bottom chord.

As Tables 3 and 4 display, 8 to 38 yielding rebar dowels are required for resisting seismic loading in each orthogonal direction of the building, depending on the effective length

Table 3. Calculated Deflections, Ductility, and Number of Rebar Dowels Required to Resist Seismic Loading in Each Orthogonal Plan Direction per AASHTO Bridge Design Ratio = 0.25.

\begin{tabular}{|c|c|c|c|c|c|c|c|c|c|c|c|}
\hline $\begin{array}{c}\text { Dowel } \\
\text { Length, } \\
\text { in } \\
(\mathbf{m m}) \\
\text { A }\end{array}$ & $\begin{array}{c}\mathbf{V}_{\text {yield }} \\
\text { lbs } \\
(\mathbf{k N})\end{array}$ & $\begin{array}{c}\Delta_{\text {dowel }} \\
\text { yield } \\
\text { (mm) }\end{array}$ & $\begin{array}{l}\Delta_{\text {limit p- }} \\
\text { Delta, in } \\
(\mathbf{m m})\end{array}$ & $\begin{array}{c}\Delta_{\text {bamboo }} \\
\text { deformation } \\
@ \mathbf{V}_{\text {yield }} \\
\text { in } \\
(\mathbf{m m}) \\
\mathbf{E}\end{array}$ & $\begin{array}{c}\text { Potential } \\
\text { Connection } \\
\text { Slip, } \Delta_{\text {slip }} \text {, in } \\
\text { (mm) } \\
\text { F }\end{array}$ & $\begin{array}{c}\begin{array}{c}\Delta_{\text {system yield }} \\
\text { in } \\
(\mathrm{mm})\end{array} \\
\mathbf{G}=\mathbf{C}+\mathrm{E}+\mathrm{F}\end{array}$ & $\begin{array}{l}\Delta_{\text {system lim }}, \text { in } \\
(\mathrm{mm})\end{array}$ & $\begin{array}{c}\text { ductility } \\
(\mu)\end{array}$ & $\mathbf{C}_{\mathrm{y}}$ & $\begin{array}{c}\text { Required } \\
\text { Number } \\
\text { of Rebar } \\
\text { Dowels, n }\end{array}$ & $\begin{array}{c}\text { System } \\
\text { strength = } \\
\mathbf{n}^{*} \mathbf{V} \mathbf{y} \\
\mathbf{l b} \\
(\mathbf{k N}) \\
\mathbf{L}\end{array}$ \\
\hline \multirow{3}{*}{$\begin{array}{c}1 \\
(25.4) \\
\end{array}$} & \multirow{3}{*}{$\begin{array}{l}756.9 \\
(3.37) \\
\end{array}$} & \multirow{3}{*}{$\begin{array}{c}0.002 \\
(0.051) \\
\end{array}$} & \multirow{3}{*}{$\begin{array}{c}0.115 \\
(2.921) \\
\end{array}$} & \multirow{3}{*}{$\begin{array}{c}0.017 \\
(0.432) \\
\end{array}$} & $0.05(1.27)$ & $0.069(1.75)$ & $0.181(4.6)$ & 2.63 & 0.58 & 8 & $6055(26.93)$ \\
\hline & & & & & $0.25(6.35)$ & $0.269(6.83)$ & $0.381(9.68)$ & 1.42 & 0.86 & 11 & $8326(37.04)$ \\
\hline & & & & & $0.50(12.7)$ & $0.519(13.18)$ & $0.631(16.03)$ & 1.22 & 0.94 & 12 & $9083(40.4)$ \\
\hline \multirow{3}{*}{$\begin{array}{c}1.5 \\
(38.1) \\
\end{array}$} & \multirow{3}{*}{$\begin{array}{l}504.6 \\
(2.24)\end{array}$} & \multirow{3}{*}{$\begin{array}{c}0.005 \\
(0.127)\end{array}$} & \multirow{3}{*}{$\begin{array}{c}0.149 \\
(3.785)\end{array}$} & \multirow{3}{*}{$\begin{array}{c}0.011 \\
(0.279)\end{array}$} & $0.05(1.27)$ & $0.066(1.68)$ & $0.21(5.33)$ & 3.17 & 0.52 & 10 & $5046(22.45)$ \\
\hline & & & & & $0.25(6.35)$ & $0.266(6.76)$ & $0.41(10.41)$ & 1.54 & 0.81 & 16 & $8074(35.91)$ \\
\hline & & & & & $0.50(12.7)$ & $0.516(13.11)$ & $0.66(16.76)$ & 1.28 & 0.91 & 18 & $9083(40.4)$ \\
\hline \multirow{3}{*}{$\begin{array}{c}2 \\
(50.8) \\
\end{array}$} & \multirow{3}{*}{$\begin{array}{c}378.5 \\
(1.684) \\
\end{array}$} & \multirow{3}{*}{$\begin{array}{c}0.009 \\
(0.229) \\
\end{array}$} & \multirow{3}{*}{$\begin{array}{c}0.175 \\
(4.445) \\
\end{array}$} & \multirow{3}{*}{$\begin{array}{c}0.008 \\
(0.203) \\
\end{array}$} & $0.05(1.27)$ & $0.067(1.7)$ & $0.233(5.92)$ & 3.46 & 0.48 & 12 & $4542(20.2)$ \\
\hline & & & & & $0.25(6.35)$ & $0.267(6.78)$ & $0.433(11)$ & 1.62 & 0.79 & 20 & $7570(33.67)$ \\
\hline & & & & & $0.50(12.7)$ & $0.517(13.13)$ & $0.683(17.35)$ & 1.32 & 0.88 & 22 & $8327(37.04)$ \\
\hline \multirow{3}{*}{$\begin{array}{c}2.5 \\
(63.5)\end{array}$} & \multirow{3}{*}{$\begin{array}{l}302.8 \\
(1.35)\end{array}$} & \multirow{3}{*}{$\begin{array}{c}0.014 \\
(0.356)\end{array}$} & \multirow{3}{*}{$\begin{array}{c}0.195 \\
(4.953)\end{array}$} & \multirow{3}{*}{$\begin{array}{c}0.007 \\
(0.118)\end{array}$} & $0.05(1.27)$ & $0.071(1.8)$ & $0.252(6.4)$ & 3.57 & 0.49 & 16 & $4845(21.55)$ \\
\hline & & & & & $0.25(6.35)$ & $0.271(6.88)$ & $0.452(11.48)$ & 1.67 & 0.76 & 24 & $7267(32.33)$ \\
\hline & & & & & $0.50(12.7)$ & $0.521(13.23)$ & $0.702(17.83)$ & 1.35 & 0.86 & 27 & $8176(36.37)$ \\
\hline \multirow{3}{*}{$\begin{array}{c}3 \\
(76.2)\end{array}$} & \multirow{3}{*}{$\begin{array}{l}252.3 \\
(1.122)\end{array}$} & \multirow{3}{*}{$\begin{array}{c}0.020 \\
(0.508)\end{array}$} & \multirow{3}{*}{$\begin{array}{c}0.212 \\
(5.385)\end{array}$} & \multirow{3}{*}{$\begin{array}{c}0.006 \\
(0.152)\end{array}$} & $0.05(1.27)$ & $0.076(1.93)$ & $0.267(6.78)$ & 3.53 & 0.49 & 19 & $4794(21.32)$ \\
\hline & & & & & $0.25(6.35)$ & $0.276(7.01)$ & $0.467(11.86)$ & 1.70 & 0.76 & 29 & $7317(32.55)$ \\
\hline & & & & & $0.50(12.7)$ & $0.526(13.36)$ & $0.717(18.21)$ & 1.36 & 0.86 & 33 & $8326(37.04)$ \\
\hline
\end{tabular}

Table 4. Calculated Deflections, Ductility, and Number of Rebar Dowels Required to Resist Seismic Loading in Each Orthogonal Plan Direction per Target Ratio = 0.10.

\begin{tabular}{|c|c|c|c|c|c|c|c|c|c|c|c|}
\hline $\begin{array}{c}\text { Dowel } \\
\text { Length, } \\
\text { in } \\
(\mathrm{mm}) \\
\text { A }\end{array}$ & $\begin{array}{l}V_{\text {yield }} \\
\text { lbs } \\
(\mathbf{k N})\end{array}$ & $\begin{array}{c}\Delta_{\text {dowel }} \\
\text { yield }, \text { in } \\
(\mathbf{m m})\end{array}$ & $\begin{array}{c}\Delta_{\text {limit P- }} \\
\text { Delta } \text { in } \\
(\mathbf{m m})\end{array}$ & $\begin{array}{c}\Delta_{\text {bamboo }} \\
\text { deformation } \\
@ \mathbf{V}_{\text {yield }}, \\
\text { in } \\
(\mathbf{m m}) \\
\text { E }\end{array}$ & $\begin{array}{c}\text { Potential } \\
\text { Connection } \\
\text { Slip, } \Delta_{\text {slip }} \text {, in } \\
\text { (mm) } \\
\text { F }\end{array}$ & $\begin{array}{c}\begin{array}{c}\Delta_{\text {system yield }}, \\
\text { in } \\
(\mathrm{mm})\end{array} \\
\mathbf{G}=\mathbf{C}+\mathbf{E}+\mathbf{F}\end{array}$ & $\begin{array}{l}\Delta_{\text {system } \lim }, \text { in } \\
\quad(\mathrm{mm})\end{array}$ & $\begin{array}{c}\text { ductility } \\
(\mu)\end{array}$ & $\mathbf{C}_{\mathrm{y}}$ & $\begin{array}{c}\text { Required } \\
\text { Number } \\
\text { of Rebar } \\
\text { Dowels, } \mathbf{n} \\
\text { K }\end{array}$ & $\begin{array}{c}\text { System } \\
\text { strength = } \\
\mathbf{n}^{*} \mathbf{V y} \\
\mathbf{l b} \\
(\mathbf{k N}) \\
\mathbf{L}\end{array}$ \\
\hline \multirow{3}{*}{$\begin{array}{c}1 \\
(25.4) \\
\end{array}$} & \multirow{3}{*}{$\begin{array}{l}756.9 \\
(3.37) \\
\end{array}$} & \multirow{3}{*}{$\begin{array}{r}0.002 \\
(0.051) \\
\end{array}$} & \multirow{3}{*}{$\begin{array}{c}0.046 \\
(1.168) \\
\end{array}$} & \multirow{3}{*}{$\begin{array}{c}0.017 \\
(0.432)\end{array}$} & $0.05(1.27)$ & $0.069(1.75)$ & $0.113(2.87)$ & 1.63 & 0.69 & 9 & $6812(30.3)$ \\
\hline & & & & & $0.25(6.35)$ & $0.269(6.83)$ & $0.313(7.95)$ & 1.16 & 0.96 & 12 & $9083(40.4)$ \\
\hline & & & & & $0.50(12.7)$ & $0.519(13.18)$ & $0.563(14.3)$ & 1.08 & 0.98 & 13 & $9840(43.77)$ \\
\hline \multirow{3}{*}{$\begin{array}{c}1.5 \\
(38.1) \\
\end{array}$} & \multirow{3}{*}{$\begin{array}{l}504.6 \\
(2.24) \\
\end{array}$} & \multirow{3}{*}{$\begin{array}{c}0.005 \\
(0.127) \\
\end{array}$} & \multirow{3}{*}{$\begin{array}{l}0.060 \\
(1.524) \\
\end{array}$} & \multirow{3}{*}{$\begin{array}{c}0.011 \\
(0.279) \\
\end{array}$} & $0.05(1.27)$ & $0.066(1.68)$ & $0.121(3.07)$ & 1.82 & 0.69 & 13 & $6560(29.18)$ \\
\hline & & & & & $0.25(6.35)$ & $0.266(6.76)$ & $0.321(8.15)$ & 1.20 & 0.96 & 18 & $9083(40.4)$ \\
\hline & & & & & $0.50(12.7)$ & $0.516(13.11)$ & $0.571(14.5)$ & 1.11 & 1.01 & 19 & $9587(42.65)$ \\
\hline \multirow{3}{*}{$\begin{array}{c}2 \\
(50.8) \\
\end{array}$} & \multirow{3}{*}{$\begin{array}{c}378.5 \\
(1.684) \\
\end{array}$} & \multirow{3}{*}{$\begin{array}{c}0.009 \\
(0.229) \\
\end{array}$} & \multirow{3}{*}{$\begin{array}{l}0.070 \\
(1.778) \\
\end{array}$} & \multirow{3}{*}{$\begin{array}{c}0.008 \\
(0.203) \\
\end{array}$} & $0.05(1.27)$ & $0.067(1.7)$ & $0.128(3.25)$ & 1.91 & 0.66 & 17 & $6435(28.62)$ \\
\hline & & & & & $0.25(6.35)$ & $0.267(6.78)$ & $0.328(8.33)$ & 1.23 & 0.94 & 24 & $9084(40.41)$ \\
\hline & & & & & $0.50(12.7)$ & $0.517(13.13)$ & $0.578(14.68)$ & 1.12 & 1.01 & 26 & $9841(43.77)$ \\
\hline \multirow{3}{*}{$\begin{array}{c}2.5 \\
(63.5) \\
\end{array}$} & \multirow{3}{*}{$\begin{array}{l}302.8 \\
(1.35) \\
\end{array}$} & \multirow{3}{*}{$\begin{array}{c}0.014 \\
(0.356) \\
\end{array}$} & \multirow{3}{*}{$\begin{array}{c}0.078 \\
(1.981) \\
\end{array}$} & \multirow{3}{*}{$\begin{array}{c}0.007 \\
(0.118) \\
\end{array}$} & $0.05(1.27)$ & $0.071(1.8)$ & $0.135(3.43)$ & 1.91 & 0.7 & 22 & $6662(29.63)$ \\
\hline & & & & & $0.25(6.35)$ & $0.271(6.88)$ & $0.335(8.51)$ & 1.24 & 0.94 & 30 & $9084(40.41)$ \\
\hline & & & & & $0.50(12.7)$ & $0.521(13.23)$ & $0.585(14.86)$ & 1.12 & 1 & 32 & $9690(43.1)$ \\
\hline \multirow{3}{*}{$\begin{array}{c}3 \\
(76.2) \\
\end{array}$} & \multirow{3}{*}{$\begin{array}{c}252.3 \\
(1.122)\end{array}$} & \multirow{3}{*}{$\begin{array}{c}0.020 \\
(0.508)\end{array}$} & \multirow{3}{*}{$\begin{array}{c}0.085 \\
(2.159)\end{array}$} & \multirow{3}{*}{$\begin{array}{c}0.006 \\
(0.152)\end{array}$} & $0.05(1.27)$ & $0.076(1.93)$ & $0.14(3.56)$ & 1.85 & 0.74 & 28 & $7064(31.42)$ \\
\hline & & & & & $0.25(6.35)$ & $0.276(7.01)$ & $0.34(8.64)$ & 1.23 & 0.95 & 36 & $9083(40.4)$ \\
\hline & & & & & $0.50(12.7)$ & $0.526(13.36)$ & $0.59(14.99)$ & 1.12 & 1 & 38 & $9587(42.65)$ \\
\hline
\end{tabular}


and P-Delta criterion used. The physical realization of the required number of rebar dowels may require additional diagonally braced bays.

\section{WIND DESIGN}

Wind loading factors were determined based on the International Building Code for 2009 (IBC-2009) per ASCE 7-05 for the Dominican Republic, since values were not available for Haiti, as follows:

Velocity pressure coefficient: $\mathrm{K}_{\mathrm{z}}=0.7$

Topographic factor: $\mathrm{K}_{\mathrm{zt}}=1.0$

Wind directionality factor: $\mathrm{K}_{\mathrm{d}}=0.85$

Wind Velocity: Wind V = 145- mph $\left(233^{-} \mathrm{km} / \mathrm{hr}\right)$

Probability of occurrence: $\mathrm{I}=1$.0

Gust factor: $\mathrm{G}=0.85$

Wall pressure coefficients: $\mathrm{C}_{\mathrm{p}}=$ see Tables 5 and 6

Internal pressure coefficients: $\mathrm{GC}_{\mathrm{pi}}=$ see Tables 5 and 6

The resulting unit pressure on a section of wall is given by:

$$
q_{i}=0.00256\left(K_{z}\right)\left(K_{z t}\right)\left(K_{d}\right)\left(V^{2}\right)
$$

Internal inward or outward pressures due to wind are tabulated below (Tables 5 through 8) with external velocity pressures and governing totals. Governing wind loading conditions are based on either negative or positive internal pressures contributing to expected roof uplift or suction. Negative pressures governed in the transverse direction while positive pressures governed in the longitudinal direction. Other constants were based on the prototype structure in Figure 4 including total roof height $=12-\mathrm{ft}$. $(3.6-\mathrm{m})$, mean roof height $=10.5^{-} \mathrm{ft}$. $(3.2-\mathrm{m})$, and a $15^{-} \mathrm{ft}(4.6-\mathrm{m})$ by $24-$ $\mathrm{ft}(7 \cdot 3-\mathrm{m})$ footprint. For this footprint, transverse loading is critical, as wind blowing in the transverse direction will generate the highest load, and the fewest number of braced frames are available to resist this load. Combining lateral roof load vectors and loading on the windward and leeward walls as applied to full height of the bamboo frame, base design shear in the transverse direction (governing condition) equals 2.55 kips $(11.3 \mathrm{kN})$ per end wall.

Combining lateral loading on the windward and leeward walls as applied to the full longitudinal surface area the pressures act upon, base design shear in the longitudinal direction equals 1.85 kips $(8.18 \mathrm{kN})$ per end wall.

\section{CONCLUDING SUMMARY}

A relatively simple bamboo framing system was devised for resisting wind and seismic loads. Utilizing a short length of rebar dowel supporting braced bamboo framing over a lowstrength concrete masonry plinth wall, the prototype system

Table 5. External and internal pressures acting on the structure's walls via wind in the transverse loading direction.

\begin{tabular}{|c|c|c|c|c|c|c|c|}
\hline \multicolumn{4}{|c|}{ Wind (N-S) Transverse Direction } & \multirow{2}{*}{$\begin{array}{c}\text { External } \\
\begin{array}{c}\text { qGC } \\
\text { psf }(\text { Pa })\end{array}\end{array}$} & \multicolumn{2}{|c|}{ Internal } & \multirow{2}{*}{$\begin{array}{c}\begin{array}{c}\text { Total Acting } \\
\text { Pressure }\end{array} \\
\text { qGC }_{\mathrm{p}}-(+) \mathbf{q}_{\mathrm{i}}\left(\mathrm{GC}_{\mathrm{pi}}\right) \\
\text { psf (Pa) }\end{array}$} \\
\hline WALL LOADING & $\mathbf{C}_{\mathbf{p}}$ & $\begin{array}{c}\mathbf{q}_{\mathrm{i}} \\
\operatorname{psf}(\mathbf{P a})\end{array}$ & $\mathbf{G C}_{\mathbf{p i}}$ & & $\begin{array}{c}\mathbf{q}_{\mathbf{i}}\left(\mathbf{G C}_{\mathrm{pip}}\right) \\
+\mathbf{p s f}(+\mathbf{P a})\end{array}$ & $\begin{array}{c}\mathbf{q}_{\mathrm{i}}\left(\mathbf{G c}_{\mathrm{pi}}\right) \\
\text {-psf }(-\mathrm{Pa})\end{array}$ & \\
\hline Windward Wall & 0.80 & $32.03(1534)$ & 0.55 & $21.78(1043)$ & $17.61(843)$ & $-17.61(-843)$ & 39.39 (1886) \\
\hline Leeward Wall & -0.50 & $32.03(1534)$ & 0.18 & $-13.61(-652)$ & $17.61(843)$ & $-17.61(-843)$ & $4(192)$ \\
\hline Side Wall & -0.70 & $32.03(1534)$ & 0.18 & $-19.06(-913)$ & $17.61(843)$ & $-17.61(-843)$ & $-1.45(-69)$ \\
\hline
\end{tabular}

Table 6. External and internal pressures acting on the structure's roof via wind in the transverse loading direction.

\begin{tabular}{|c|c|c|c|c|c|c|c|}
\hline \multicolumn{4}{|c|}{ Wind (N-S) Transverse Direction } & \multirow{2}{*}{$\begin{array}{c}\text { External } \\
\text { qGC }_{p} \\
\text { psf (Pa) }\end{array}$} & \multicolumn{2}{|c|}{ Internal } & \multirow{2}{*}{$\begin{array}{c}\text { Total Acting } \\
\text { Pressure } \\
\text { qGC }_{\mathrm{p}}-(+) \mathrm{q}_{\mathrm{i}}\left(\mathrm{GC}_{\mathrm{pi}}\right) \\
\operatorname{psf}(\mathrm{Pa})\end{array}$} \\
\hline ROOF LOADING & $\mathbf{C}_{\mathbf{p}}$ & $\begin{array}{c}\mathbf{q}_{\mathbf{i}} \\
\operatorname{psf}(\mathbf{P a})\end{array}$ & $\mathbf{G C}_{\mathbf{p i}}$ & & $\begin{array}{c}\mathbf{q}_{\mathbf{i}}\left(\mathbf{G C}_{\mathrm{pi}}\right) \\
+\operatorname{psf}(+\mathbf{P a})\end{array}$ & $\begin{array}{c}q_{i}\left(G c_{p i}\right) \\
-p s f(-P a)\end{array}$ & \\
\hline Windward & 0.70 & $32.03(1534)$ & 0.55 & $19.06(913)$ & $17.61(843)$ & $-17.61(-843)$ & $36.67(1756)$ \\
\hline Overhang & 0.80 & $32.03(1534)$ & 0.18 & $21.78(1043)$ & $\mathrm{N} / \mathrm{A}$ & $\mathrm{N} / \mathrm{A}$ & $21.78(1043)$ \\
\hline Leeward & -0.60 & $32.03(1534)$ & 0.18 & $-16.33(-782)$ & $17.61(843)$ & $-17.61(-843)$ & $1.28(61)$ \\
\hline Overhang & 0.80 & $32.03(1534)$ & 0.18 & 21.78 (1043) & $\mathrm{N} / \mathrm{A}$ & $\mathrm{N} / \mathrm{A}$ & 21.78 (1043) \\
\hline
\end{tabular}

Table 7. External and internal pressures acting on the structure's roof via wind in the longitudinal loading direction.

\begin{tabular}{|c|c|c|c|c|c|c|c|}
\hline \multicolumn{4}{|c|}{ Wind (W-E) Longitudinal Direction } & \multirow{2}{*}{$\begin{array}{c}\text { External } \\
\text { qGC } \\
\text { psf (Pa) }\end{array}$} & \multicolumn{2}{|c|}{ Internal } & \multirow{2}{*}{$\begin{array}{c}\text { Total Acting } \\
\text { Pressure } \\
\text { qGC }_{\mathbf{p}}-(+) q_{i}\left(G_{C_{p i}}\right) \\
\text { psf }(\mathbf{P a})\end{array}$} \\
\hline WALL LOADING & $\mathbf{C}_{\mathbf{p}}$ & $\begin{array}{c}\mathbf{q}_{\mathbf{i}} \\
\operatorname{psf}(\mathbf{P a})\end{array}$ & $\mathbf{G C}_{\mathbf{p i}}$ & & $\begin{array}{c}\mathbf{q}_{\mathbf{i}}\left(\mathrm{GC}_{\mathrm{pi}}\right) \\
+\mathbf{p s f}(+\mathbf{P a})\end{array}$ & $\begin{array}{c}q_{i}\left(G c_{p i}\right) \\
-p s f(-P a)\end{array}$ & \\
\hline Windward & 0.80 & $32.03(1534)$ & 0.18 & $21.78(1043)$ & $5 \cdot 76(276)$ & $-5 \cdot 76(-276)$ & $16.02(767)$ \\
\hline Leeward & -0.40 & $32.03(1534)$ & 0.18 & $-10.89(-521)$ & $5 \cdot 76(276)$ & $-5 \cdot 76(-276)$ & $-16.05(-768)$ \\
\hline Side & -0.70 & 32.03 (1534) & 0.18 & $-19.06(-913)$ & $5.76(276)$ & $-5.76(-276)$ & $-24.82(-1188)$ \\
\hline
\end{tabular}


Table 8. External and internal pressures acting on the structure's roof via wind in the longitudinal loading direction.

\begin{tabular}{|c|c|c|c|c|c|c|c|c|}
\hline \multicolumn{5}{|c|}{ Wind (W-E) Longitudinal Direction } & \multirow{3}{*}{$\begin{array}{c}\text { External } \\
\text { qGC }_{\mathbf{p}} \\
\text { psf (Pa) } \\
-24.5(-1173)\end{array}$} & \multicolumn{2}{|c|}{ Internal } & \multirow{3}{*}{$\begin{array}{c}\begin{array}{c}\text { Total Acting } \\
\text { Pressure }\end{array} \\
\text { qGC }_{\mathbf{p}}-(+) \mathbf{q}_{\mathrm{i}}\left(\mathbf{G C}_{\mathbf{p i}}\right) \\
\text { psf (Pa) } \\
-30.26(-1449) \\
\end{array}$} \\
\hline \multicolumn{2}{|c|}{$\begin{array}{c}\text { Length of Roof } \\
\text { Pressure Acts On, } \\
\text { ft (m) }\end{array}$} & $\mathbf{C}_{\mathrm{p}}$ & $\begin{array}{c}\mathbf{q}_{\mathbf{i}} \\
\operatorname{psf}(\mathbf{P a})\end{array}$ & $\mathbf{G C}_{\mathrm{pi}}$ & & $\begin{array}{c}\mathbf{q}_{\mathbf{i}}\left(\mathbf{G C}_{\mathbf{p i}}\right) \\
+\mathbf{p s f}(+\mathbf{P a})\end{array}$ & $\begin{array}{c}\mathbf{q}_{\mathbf{i}}\left(\mathbf{G c}_{\mathbf{p i}}\right) \\
-\mathbf{p s f}(-\mathbf{P a})\end{array}$ & \\
\hline o (o) & $6(1.83)$ & -0.90 & $32.03(1534)$ & 0.18 & & $5 \cdot 76(276)$ & $-5.76(-276)$ & \\
\hline $6(1.83)$ & $12(3.66)$ & -0.90 & $32.03(1534)$ & 0.18 & $-24.5(-1173)$ & $5.76(276)$ & $-5.76(-276)$ & $-30.26(-1449)$ \\
\hline $12(3.66)$ & $24(7.32)$ & -0.50 & $32.03(1534)$ & 0.18 & $-13.61(-652)$ & $5.76(276)$ & $-5.76(-276)$ & $-19.37(-927)$ \\
\hline
\end{tabular}

Table 9. Number of dowels, $n$, required along each perimeter frame line to resist design base shear. (Governing values shown in bold type).

\begin{tabular}{|c|c|c|c|c|}
\hline $\begin{array}{c}\text { Length of } \\
\text { Rebar (in) }\end{array}$ & $\begin{array}{c}\mathbf{V}_{\text {yield }}, \mathbf{l b s} \\
(\mathbf{k N})\end{array}$ & $\begin{array}{c}\text { (n) Seismic } \\
\text { Loading }\end{array}$ & $\begin{array}{c}\text { (n) Transverse } \\
\text { Wind Loading }\end{array}$ & $\begin{array}{c}\text { (n) Longitudinal } \\
\text { Wind Loading }\end{array}$ \\
\hline 1.0 & $756.9(3.37)$ & $\mathbf{1 2}$ & 6 & 3 \\
\hline 1.5 & $504.6(2.24)$ & $\mathbf{1 8}$ & 8 & 4 \\
\hline 2.0 & $378.5(1.68)$ & $\mathbf{2 2}$ & 11 & 5 \\
\hline 2.5 & $302.8(1.35)$ & $\mathbf{2 7}$ & 13 & 8 \\
\hline 3.0 & $252.3(1.12)$ & $\mathbf{3 3}$ & 16 & 8 \\
\hline
\end{tabular}

has base shear strength governed by seismic design. Table 9 summarizes the number of potentially yielding dowels required to provide sufficient base shear strength for the building system, based on the more lenient AASHTO P-Delta criterion, and assuming that bamboo connections are achieved that result in no more than $0.5 \mathrm{in} .(12 \mathrm{~mm})$ of lateral displacement at the roof level at the force associated with plastification of the rebar dowels.

The proposed structure (Figure 4) provides for six columns in the shorter length of wall with probability of more to accommodate brace connections and corner conditions. It is possible to utilize a bottom chord, just above the plinth wall, to connect all columns together to mobilize every rebar dowel to resist base shear. Other possible methods to accommodate more rebar dowels (n) are doubling or quadrupling the number of culms at each column location, or perhaps increasing the number of rebar dowels in each culm.

Further work is underway to test full scale frames. In addition, as recommended in Section 2.5, experimental work is ongoing to study the effectiveness of steel annular inserts or other materials to maintain the effective length of the rebar dowels.

\section{ACKNOWLEDGMENTS}

Developments described herein were achieved in collaboration with Bruce King, P.E., of the Ecological Building Network, with assistance from Darrel DeBoer, Architect, and Martin Hammer, Architect. We appreciate the opportunity to work with these talented individuals towards the development of culturally appropriate and low-impact housing systems for reconstruction.

\section{REFERENCES}

(1) EERI. (May, 2010). The $M_{w}$ 7.o Haiti Earthquake of January 12, 2010: Report \#2, EERI. Special Earthquake Report. Earthquake Engineering Research Institute.

(2) DesRoches, R. R., Kurtis, K. E., Gresham, J. J. (2011). Breaking the reconstruction logjam: Haiti urged to recycle concrete rubble. American Ceramic Society Bulletin, 90(1): 20-26.

(3) Federal Research Division. (May, 2006). Country Profile: Haiti. Federal Research Division-Library of Congress. http:// lcweb2.loc.gov/frd/cs/profiles/Haiti.pdf.

(4) USAID. (April, 2010). Emergency Market Mapping and Analysis: The Market for Agricultural Labor in Sud-Est Department of Haiti. MicroReport \#165. United States Agency for International Development.

(5) Vance, E.D., Maguire, D. A., Zalesny Jr., R. S. (June, 2010). Research Strategies for Increasing Productivity of Intensively Managed Forest Plantations. Journal of Forestry, pp. 183-192.

(6) Blatner, K.A., Cohn, P. J., Fight, R. D. (2010). Returns from Management of Noble Fir Stands for Bough Production and Sawtimber. Western Journal of Applied Forestry, 25(2): 68-72.

(7) Marcklinger, C. J. (2011). Community Environmental Preservation Initiative in Borgne, Haiti. FIU Electronic Thesis and Dissertations, Paper 403.

(8) Perez, M. R., Belcher, B., Maoyi, F., Xiasheng, Y. (2003). Forestry, poverty, and rural development: perspectives from the bamboo subsector. En Hyde, W. F., Xu, J., Belcher, B. (Eds.) China's Forests: Global Lessons from Market Reforms, (pp. 151-176). Washington D.C.: Resources for the Future and CIFOR.

(9) Van Der Lugt, P. (2005). The bamboo sector in Colombia and Ecuador: a state of the art analysis of opportunities and constraints. Journal of Bamboo and Rattan, 4(4): 421-440, doi: http://dx.doi.org/10.1163/156915905775008408. 
(10) Riano, N.M., Londono, X., Lopez, Y., Gomez, J.H. (2002). Plant growth and biomass distribution on Guadua angustifolia Kunth in relation to ageing in the Valle Del Cauca - Columbia. Bamboo Science and Culture: The Journal of the American Bamboo Society, 16(1): 43-51.

(11) Trujillo, D. J. A. (6-9 September, 2009). Axially Loaded Connections in Guadua Bamboo. In Proceedings of the International Conference on Non-conventional Materials and Technologies. Bath, UK.

(12) Lopez, D. P. (2009). Desarrollo de un Sistema de Construcción a partir de estructuras en Guadua. Medellín, Colombia: Universidad EAFIT - Ingeniería de Diseño de Producto.

(13) BME Capstone Design Group. (2011). Bamboo wikispaces. Arizona State University. http://bamboo.wikispaces.asu. edu/4.+Bamboo+Properties.

(14) Rottke, E. (6 June, 2003). Bambus Engineering Reports/Mechanical Properties. http://bambus.rwth-aachen.de/eng/ reports/mechanical_properties/referat2.html.

(15) Frankel, A., Harmsen, S, Mueller, C., Haase, J. (2010). Documentation for the Initial Seismic Hazards Maps for Haiti, Open File Report 2010-1067, U.S. Geological Survey. http://pubs.usgs.gov/of/2010/1067/.

(16) Aschheim, M., Black, E. (2000). Yield Point Spectra for Seismic Design and Rehabilitation. Earthquake Spectra, Earthquake Engineering Research Institute, 16(2):317-335, doi: http://dx.doi.org/10.1193/1.1586115.

(17) AASHTO. (2012). AASHTO Guide Specification for LRFD Seismic Bridge Design, $2^{\text {nd }}$ Edition (2011 with 2012 interim revisions). Washington, D.C.: American Association of State Highway and Transportation Officials.

(18) Caltrans SDC. (2010). Caltrans Seismic Design Criteria version 1.6. Sacramento, California: California Department of Transportation.

(19) FEMA 440. (June, 2005). Improvement of Nonlinear Static Seismic Analysis Procedures. Report FEMA-440. Washington: Federal Emergency Management Agency.

(20) Echeverria, J., Sampson, C., Vargas, J., Nilsson, T., Gil-Martin, L. M., Aschheim, M. (June, 2013). Development of a Seismic-Resistant Bamboo Braced Frame System for Resisting Earthquakes in Tropical Climates. In $2^{\text {nd }}$ International Congress on Mechanical Models in Structural Engineering. Granada, Spain.

$$
* * *
$$

